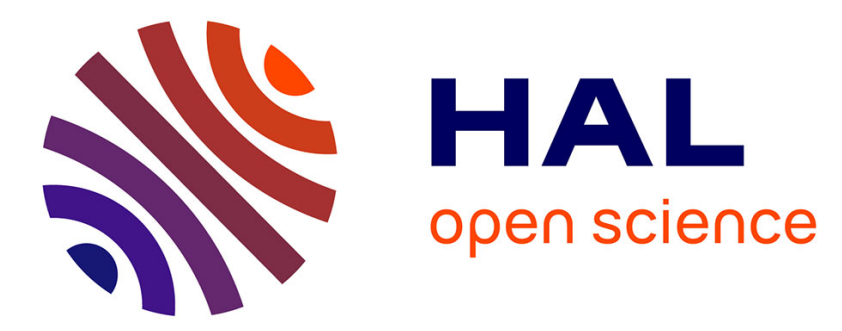

\title{
Designing Paris Gare du Nord for pedestrians or for clients? New retail patterns as flow optimization strategies \\ Nacima Baron
}

\section{- To cite this version:}

Nacima Baron. Designing Paris Gare du Nord for pedestrians or for clients? New retail patterns as flow optimization strategies. European Planning Studies, 2019, 27, pp.618 - 637. 10.1080/09654313.2018.1562651 . hal-03246876

\section{HAL Id: hal-03246876 \\ https://hal-enpc.archives-ouvertes.fr/hal-03246876}

Submitted on 2 Jun 2021

HAL is a multi-disciplinary open access archive for the deposit and dissemination of scientific research documents, whether they are published or not. The documents may come from teaching and research institutions in France or abroad, or from public or private research centers.
L'archive ouverte pluridisciplinaire HAL, est destinée au dépôt et à la diffusion de documents scientifiques de niveau recherche, publiés ou non, émanant des établissements d'enseignement et de recherche français ou étrangers, des laboratoires publics ou privés. 


\title{
Designing Paris Gare du Nord for pedestriansor for clients? New retail patterns as flow optimization strategies
}

\author{
Nacima Baron
}

To cite this article: Nacima Baron (2019)

Designing Paris Gare du Nord for pedestrians

or for clients? New retail patterns as flow

optimization strategies, European Planning

Studies, 27:3, 618-637, DOI:

10.1080/09654313.2018.1562651

\section{Designing Paris Gare du Nord for pedestrians or for clients? New retail patterns as flow optimization strategies}

\author{
Nacima Baron \\ Laboratoire Ville Mobilité Transport, Ecole Nationale des Ponts et Chaussées, University Paris Est, Marne la \\ Vallée, France
}

This article explores the links between flow management and retail development in railway stations. Questioning the way in which planners as well as station managers consider the relations between movement and commerciality, it combines theoretical insight and empirical findings at Paris Gare du Nord. In the planning literature, the progress of pedestrian traffic models andthe social understanding of passenger behaviour have long been perceived as separate scientific goals. Today, however, the two domains are converging towards a more comprehensive approach, which in recent times has become a crucial aspect of railway competition strategies. In light of this, dynamic mapping conducted over the period 2010-2017 at Paris Gare du Nord shows how railway designers are reorganizing space to foster free movement and consumption. The article concludes with the presentation and discussion of two main principles of station retail planning and design. First, the production of a 'servicescape' through the intensification of nudge strategies. Second, the delivery of a 'stationscape' based on the use of trademarks as landmarks and a threedimensional design that accentuates the socio-economic fragmentation of space. 


\section{Introduction}

What are the connections in major HS hubs between increases in traffic and the develop-ment of commercial activity? On the one hand, facilitating mobility within HS stations entails releasing space to give users greater freedom of movement. At the same time, as a result of commercial development, retail spaces are expanding and the space dedicatedto movement is diminishing, with the result that window-shopping is reducing overall speed of movement. As Dang Vu \& Jeanneau recognize in their observation of the recently refurbished Gare Saint Lazare in Paris, railway stations are increasingly managed as com-mercial sites, and, consequently, mobility growth and retail development may seem to becontradictory trends (Dang Vu \& Jeanneau, 2008).

Yet, in France as in many other European countries, Gares\&Connexions, the public entity that runs stations on behalf of the historical rail operator SNCF, claims not only 
that commercial development and free flowing movement within stations are perfectly compatible, but that they are interdependent. Following Ropert, the station operator assumes that a good pedestrian traffic system ultimately makes HS stations commerciallyprofitable, and conversely, that good retail spaces impact favourably on ease of movement(Ropert, 2017, p. 75). The logic behind this view is as follows: a rise in user numbers creates greater consumer demand, with the result that people spend more in HS stations. Because of this greater commercial intensity, the operator is able to raise the prices of its commer-cial leases, and therefore obtain an increase in commercial revenue. This increased funding opens up possibilities of two types. Either the station operator limits the level of regulated revenues that the HS rail companies pay to access a station, and this may gradually reduceHS ticket prices, thereby increasing the modal share of rail and therefore footfall within stations; or, the station operator can use this income to expand and modernize the asset and thereby improve the conditions of movement (Figure 1).

This article begins by examining this paradoxical yet apparently virtuous circle. It explores to what extent the rail operator is able to combine flow optimization and commercial attractiveness in HS stations both strategically and spatially, and why this positioning is also of great interest to retailers (Les Echos, 2013). The objective of the demonstration is twofold. First, to identify what is really innovative in the spatial layouts and design principles currently implemented in HS railway hubs. Having precisely mapped the removal and relocation of all facilities at Paris Gare du Nord between 2010 and 2017, one research finding is that retail not only adds value as another dimension of the rail service, but it is supported because it is becoming one of the most sophisticated techniques of flow intensification in major hubs. The second goal is to address more theoretically the relation between two objects that have traditionally been constructed as separate in planning studies and research on urban mobilities, because of their distinct conceptual and methodological backgrounds. I will therefore explore the possibility of reconnecting the figure of the HS station user as a pedestrian who, in line with most transit models, walks directly to the platforms and objects to wasting time in crowds, with the figure of the user as a HS station client, happy to loiter and stroll around while waiting for the train. This is why the text is divided into four sections, starting

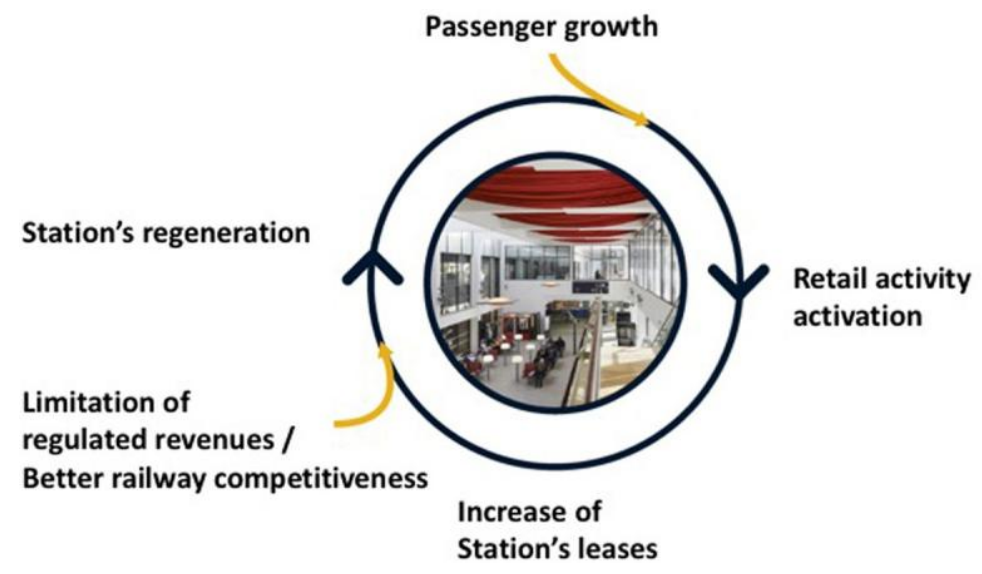

Figure 1. Railway Company circular argumentation. 
from a literature review that reveals the dualistic planning research traditions in station movement analysis, then explaining the factors in retail redevelopment pursued by the French rail company. An exhaustive empirical mapping of retail relocation at Paris Gare du Nord between 2010 and 2017 will then demonstrate the main innovative aspects of station retail design and planning.

\section{Pedestrian traffic models and retail development analysis in railway stations: a dualistic research tradition}

\section{Railway retail, important criteria for HS station typologies and service level assessment}

The railway station is a complex object where planning, design and management practices have to be approached holistically (Ross, 2000). The location of the station and its position relative to the rail network and the city, the dimensions of platforms and the capacity to handle large flows at peak times, the surface area and layout of indoor and outdoor environments, are all considered of great importance (Debayles-Oki \& Doumas, 2006). Service areas such as ticketing facilities, restaurants and shops are perceived as crucial amenities (Hale, 2013; Pięt, 2012; Ribeill, 1996). Such services are analysed in the planning literature as a functional and necessary component of any station, helping to define or achieve a particular level of service for HS station especially (Zemp, Stauff acher, Lang, $\&$ Scholz, 2011). However, scholars also take the view that service should be assigned a separate space and physical limits in order to prevent potential countereff ects and, perhaps a decline in station performance.

In Europe, the increasing presence of shops, introduced either within the context of refurbishment products or in the construction of new HS stations, has attracted the interest of many planners from diff erent perspectives after a great work was done in airport retail analysis.

Airport retail is old and well-established compared with the station retail model. Its origin lies mainly in the importance of duty-free, which was first introduced at Shannon Airport in 1947 to serve passengers travelling between North America and Europe (they had time to buy while refuelling the transatlantic planes). Since its inclusion in the Convention on International Travel in 1954, duty and tax free shopping has changed a lot, together with the regulatory framework surrounding it (long and short term leases, concessions and franchises). The design of retail spaces is constantly being adapted to off er (as operators say) the 'ultimate shopping experience', however, there is fierce competition between airport and HS station retail strategies, however, many diff erences persist. Airport shopping areas are split between international zones, Schengen zones and public zones, while station have (until now) been less concerned with security thresholds. Nonetheless, common trends are appearing, such as the expansion of retail zones, the acceleration of brand turn-over or the relocating of haute cuisine. Parisian railway stations have already 3 'chefs', while Orly and Roissy are looking to install 8 starred restaurants by 2020.

In this line, returning to railway system, Julie Cidell and David Pryterch see the presence of retail as a symbol of the production of urban space within a transport infrastructure (Cidell \& Pryterch, 2015). Deike Peters sees the pressure for the development of malls in or around railway stations as linked to metropolitan megaprojects. Luca Bertolini 
observes retail activity as a key criterion in station classification (Bertolini \& Spit, 1998), the surface area and type of retail outlet helping to define whether the primary focus of a station is its transport function or, conversely, whether it should be perceived as an urban space. In other station typologies (Zemp, Stauff acher, Lang, \& Scholz, 2011), service and especially commercial activity in and around HS stations (this distinction is quite impor-tant) are also taken into account, and presented as normal, and even necessary (Peek \& Van Hagen, 2002).

Many passengers enjoy shopping and window-shopping while transferring trains and waiting in the station. Such passenger behavior causes issues such as crossing of the passengers' flow and the decline in walking speed. Therefore, it is important to consider such behavioral patterns in the planning and management of facilities in the railway station.

This line quoted in Yamashita, Uchiyana and Hibino (2007, p. 808) shows the potentially problematic, even controversial aspect of station retail. These authors recommend that commercial activity should be rationed in planning and management strategies, with retail outlets being allocated separate spaces and a careful balance maintained between profitability and fluidity targets. The solution of strict separation between circulation spaces and commercial functions is also proposed by Peek \& Van Hagen, who write:

A station should be divided into three areas. First, travel-related services located at the center of transfer points with acceleration of flows as the key word here. Second, business facilities central to transfer points would make transfer intervals more useful and pleasant; the emphasis is on enhancing comfort and experience. Third, less travel-related activities and attractions should be concentrated in a particular location, thus reducing travel time and hassle and enhancing the urban environment (page 3).

Other scholars, conversely, argue in favour of maximizing station service levels and service quality, in other words giving 'all conditions to the satisfy customer physical needs, capacity of movement and comfort' (Pitsiava-Latinopoulou \& Iordanopoulos, 2012, p. 3298). These recommend locating shops as close as possible to passenger flows. All, nevertheless, consider further research on the behavioural patterns of station users as urgent, in order to understand and predict the responses of rail passengers to commercial stimulation.

\section{Station pedestrian and railway retail customer: two irreconciliable research objects?}

The need to link and simultaneously separate service and flows in stations is based on empirical evidence, but may also be associated with a divide that continues to structure station planning tradition. While there is not enough space here to fully describe the origins and progress of HS station planning, I will show here that the research domains of pedestrian traffic and of user behaviour arise from very diff erent epistemes.

Academics have been producing station pedestrian flow models since the 1980s, first on the basis of experimental observations (Daamen \& Hoogendoorn, 2004), then with more sophisticated probabilistic tools (Banos \& Pare, 2009). This work entails the identification of flow characteristics and trajectories, together with discussions of density and fluidity levels based on design tables and manuals (Fruin, 1971). Today, new developments in this field consist in incorporating into the models a more complex - i.e. a qualitative and behavioural - picture of each pedestrian (Paris, 2007). The challenge is to convert a 
mechanical mobile object into a real subject with practices (buying, waiting, using a digital device) and emotions (stress or satisfaction) that relate to environmental and contextual variables (Löfgren, 2008). There is a kind of continuous race between research and growing HS station complexity. The models need always to be enhanced, because 'showrooms, retail and facilities grasp passengers' attention and deroute their direction and speed patterns' (Yamashita et al., 2007, p. 814).

The social sciences also document HS station retail development through the lens of metropolization and public space production (Ban, 2008; Xue, Ma, \& Hui Ka, 2012). In French urban sociology, an important step was made at the end of the 1980s, inspired by the American pragmatist school of psychology (Gibson, 2015) and sociology (Goff man, 1963). One of the most emblematic authors in this tradition, Isaac Joseph, chose HS railway stations as a medium for the exploration of social life and public space (Clot-Goudard \& Tillous, 2008). Concepts such as Gibson's 'aff ordance' and Goff man's 'interaction' were applied to HS stations in order to characterize the social interactions between users, or between a buyer and seller in a ticket office or a railway retail outlet. Isaac Joseph played an important role in addressing the function and meaning of the spatial transformation taking place in Gare du nord. He also developed new methods such as immersive exploration, transect analyses, and in-depth interviews (Battegay \& Tarrius, 1995; Bayart, 1996; Proust, 1996).

This sociological corpus was later enriched by research focusing on retail. Academics, planners and designers explored changes in retail spatial patterns in HS stations and showed the diversification of station retail typologies from the mall model (Goss, 1993) to more varied configurations such as flexible new store formats, retail extensions and brand diversification (Haans, 2011). Other planners have focused on the attitudes of retail consumers, defining them as 'opportunist shoppers' (Gary, 1995). Gasnier (2007) connects the practice of shopping in a HS station with broader transformations in the way of life and in the social use of time. Exploring the behaviour of mobile rail consumers a little further, Monnet and Staszak (2008) describe several buying styles, from routinized invisible consumption (such as buying a newspaper) to opportunity buying (during a halt at an exchange hub).

At present, it is not easy for scientists to identify where the balance lies between station under-commodification, which is negative for station operation, and overcommercialisation, which may negatively aff ect transport performance. The two currents of research work in separate fields but converge in one point: the need to address more profoundly behavioural factors and to consider passengers or station users not as passive objects but as complex social subjects. Applied marketing produced in the executive offices of railway companies, which try to convert HS users into potential clients, considers also this question very seriously.

\section{Designing French railway stations as service places: legal drivers and business strategies}

\section{Traffic streaming and commerciality in France's big stations: two dynamicslinked by legal factors}

The eff orts of rail operators are not restricted to bringing more stores closer to passengers. They involve developing strategies and designing layouts to merge pedestrian traffic space 
with commercial opportunities. This may be understood, to begin with, as an adaptation to a new normative and competitive framework.

Stations and the entities that operate them have undergone major institutional changes in the last twenty years, in response to a European directive requiring the unbundling of infrastructure operation from train operation (Riot, 2014). Across Europe, station management has gradually (but uncompletely) been taken out of the hands of the historic national rail operators, and station operators have to adopt a position of growing neutrality towards the diff erent rail operators and HS operators that use their stations. In France, the station operator Gares\&Connexions is still entirely state-owned, but it finances major station upgrading projects from two kinds of income (Baron \& Roseau, 2016). First, fees paid by the regulated sector (for train access to stations and for the use of station premises: ticket offi ces, technical premises ...), and second, deregulated income earned from the leasing of retail space (Desruelles, 2009). This means that making stations both attractive for train operators and profitable for retailers are two planks of a station development strategythat begins with a radical change in the role of the station operator.

Following the legal and institutional changes, the station operator now works with a series of 'customers': partnerships with rail and HS companies, financial and real estate entities, commercial developers (B2B); station users (B2C); the other public institutions (B2G). Station flows are a central topic in the negotiations conducted with all three clienteles. The volume and sociodemographic characteristics of these flows are essential parameters in the profitability of B2B operations. Smooth flows within stations generate customer satisfaction, which is central to a good B2C relationship. Finally, social acceptance of changes to the station, the quality of its integration into the urban environment, its role as an attractive presence in a neighbourhood, are key to good B2G relations. Therefore, flow is a construction, insofar as it is not just something that is quantified, or even smoothly accommodated, but something that is increasingly produced by means of strategic business choices.

HS Railway station flow design and management is a professional skill at the intersection between engineering, planning and marketing techniques. Today, this combination of scientific knowledge and empirical know-how produced in the headquarters of railway companies is being integrated into a new strategy, which includes a new station metric.

In geography, a metric is more than a measurement of distance, it is a way of determining relations of spatial and temporal order and magnitude. In our context, it begins with the conversion of time units into spatial units and leads to the construction of two indicators, rush hour and 'allowance time' (i.e. the time passengers allow before the scheduled departure time of their train). Station sizing, in other words the station's optimum volume, depends on the maximum number of users present at a given moment. Rush-hour thus determines the minimum capacity of the smallest spatial components (train platforms, stairways, etc.), and forms the basis for a series of calculations on flow rate used to calibrate the spaces of movement (Kärrholm, 2009). Combining the allowance time with the value assigned to the pedestrian's relative speeds on the basis of endogenous variables (sex, age, luggage quantity ...), produces a given configuration for the pedestrian flow within a HS station.

Flow management then consists in a series of operations to translate the spatiotemporal characteristics of the movement of all the pedestrians within the HS station into the required metric. Then, once each of these pedestrians has the capacity to react to 
informational or commercial stimuli, the station operator is in a position to manage the HS station around flows, by means of audible or digital messages relating to both planned and unplanned events (ticket sales, train departures, etc.) (Shankar et al., 2016).

The second driver of French railway retail strategy comes from commercial law adaptation. Article R 145-6 of France's Commercial Law defines the commerciality of a station as the extent to which it enables tradespeople who do business there to make profit as a result of the qualities of the place alone, regardless of the abilities of the store operators (Merle \& Fauchon, 2018). The potential commerciality of a store depends on several factors, among them its location and position relative to traffic flows or the appeal of its surroundings (Anic, Radas, \& Lim Lewis, 2010). An improvement in these criteria can justify an increase in the value of the lease, and therefore an increase in rents and fees. That is why the French station operator is trying to maximize the rental value by combining growth in the numbers of station spaces with growth in station intrinsic commerciality quality. Its targets for the period 2016-2025 are ambitious. Among the 400 stations containing at least one retail outlet (about $10 \%$ of all stations across the country), retail space is planned to grow by $50 \%$ to 300,000 square metres, while fee revenues are slated to double (SNCF, 2016), though still leaving SNCF a minority player, with around $30 \%$ of market share, compared with the airport sector players, which hold $50 \%$ of the potential market.

What is at stake here is nothing less than a transformation of the whole railway business. By applying new flow streaming principles to station and, first of all, to hubs and HS stations, the company is pursuing market diversification (following the path of Japanese companies, Suzuki 2017). This means a possible shift in the company's role from managing an asset burden (in France, it consists in maintaining 4000 stations, representing 2 billion square metres, which is expensive) to that of a specialist in harvesting flows and generating profits from moving people.

HSR companies are greatly aff ected by the level of service they may off er to their clients in each HS station. Metropolitan stations, especially when they combine short distance and commuting services with long distance and HS services (As can be also verified in other countries, see Hale \& Miler, 2013), are rigourously segmented. They provide three diff erent types of retail services. Basic services (newsagents, cafés) are mainly used by commuters and by HS business repeaters who spend ten to twenty minutes inside the station before boarding. Essential services cover a wider range of food and drink outlets and target business and leisure clients spending about half an hour inside the station. Finally, comfort services include a wider range of stores, the waiting time being about an hour for long distance trips, especially on Thalys and Eurostar trains. These kinds of combined stations are becoming ideal playgrounds for smart retail innovations. New retail possibilities are constantly being tested, such as the possibility for a VIP HS user trapped on a crowded platform to order a meal by phone for delivery by an Amazon Prime Air type drone.

Let us now explore how this reasoning has gradually been applied to France's and Europe's biggest station, Paris Gare du Nord.

\section{Gare du Nord recurrent refurbishment programmes}

Because of its location in Paris and its successive historical transformations, because of the volume of traffic it handles and the complex social and racial portrait it provides of the capital, Paris Gare du nord is undoubtedly France's most thoroughly studied station 
(Bowie, 1996; Clozier, 1942; Joseph, 1995; Traoré Porna, 2008). Being located at the interface between central districts and the new northern suburbs of Seine-Saint-Denis, with Stade de France and other future sport facilities, the old station is the object of new architectural transformations for the 2024 Olympic bid. It is already a huge hub. Daily passenger count at the Gare du Nord is about 700,000 travellers in a busy day and the stations operates daily 2100 trains. The current flows account for the presence of 110 retail outlets in the station, generating $€ 16$ million in annual revenues (excluding parking and advertising) (Table 1). Traffi c surveys forecast a 26.7\% increase in passenger traffi c by 2020 resulting from the introduction of new and larger capacity rolling stock. The current 750 -seat TGV Eurostar is to be replaced by a 900-seat model, while the Ile-de-France transport organizing authority is replacing its existing trains (with capacity of 570 passengers) by vehicles with capacity of up to 1540 . This increase in flows will aff ect the sections of thecross-platform diff erently: on the western side, an additional $20 \%$ passengers will be dis- gorged from Eurostar and Thalys, whereas at the eastern end, intercity and regional service (TER) is likely to handle a further 34\% traffic (Wilmotte, 2016).

Retail areas are very unevenly distributed across the diff erent levels, and this is the result of three generations of refurbishment programmes in recent times. The hub off ers a wide variety of lines and rail provision and off ers correspondences and connections between regional trains, high-speed trains, intercity and interregional trains, regional express network (RER) and metro. The station's most recent aboveground architectural changes coincided with the arrival of high-speed rail in the 1990s (TGV to Lille in 1991, Eurostar service for the link with England in 1994, then Thalys in 1996 to cities in Belgium, Germany and the Netherlands) and justified a modernization programme, marked by the first application of SNCF's retail strategy. In 1998, the internal Gares en mouvement [stations on the move] programme provided the framework for the company's transition from an industrial entity to a service entreprise (Duchemin, 1999; Perrin, 1998; Pouvelle, 1998). Favin Lévêque was one of the first leader of the company to impagine partnerships with real estate and distribution firms to commercialize retail spaces (Favin-Lévêque, 2005).

In the early 2000s, further redevelopment was carried out on the western part of the station, its facade and basement, in order to facilitate connections between the main lines, the RER and the Metro. This moment may be viewed as a second step in the development of traffic and commercial exploitation schemes, more in line with the mass transit revolution occurring at this time. In fact, Gare du nord was primarily a metropolitan inter-change hub used $75 \%$ by commuters, many of them moving between diff erent types of rail service. The needs of commuters were met by a big mall-like transfer lounge in the sub-

Table 1. Paris Gare du Nord spatial organization and retail profitability.

\begin{tabular}{llllcc}
$\begin{array}{l}\text { Gare du Nord } \\
\text { levels }\end{array}$ & Access & \multicolumn{1}{c}{ Train Services } & $\begin{array}{c}\text { Passenger } \\
\text { typology }\end{array}$ & $\begin{array}{c}\% \text { on all station } \\
\text { retail rev. }\end{array}$ & $\begin{array}{c}\text { Approx. Retail revenue } \\
€ / \mathrm{m}^{2} / \text { year }\end{array}$ \\
\hline $\begin{array}{l}\text { Eurostar } \\
\text { Mezzanine }\end{array}$ & Limited & International & $\begin{array}{c}\text { Business } \\
\text { Leisure }\end{array}$ & 18 & 6200 \\
$\begin{array}{c}\text { Basement Level } \\
\text { Main }\end{array}$ & Free & $\begin{array}{c}\text { International, National, } \\
\text { Regional }\end{array}$ & $\begin{array}{c}\text { Business } \\
\text { Leisure }\end{array}$ & 40 & 2500 \\
$\begin{array}{l}\text { concourse } \\
\text { Underground }-1\end{array}$ & Free & Metro and Regional & $\begin{array}{c}\text { Commuting } \\
\text { Commuting }\end{array}$ & 9 & 3000 \\
Underground -2 & Limited & Metro & Commuting & 33 & 2400 \\
\hline
\end{tabular}


basement, providing 2400 square metres of retail space, with around 40 outlets (Périer, 2003). The collection of stores opened under a common banner 'Boutiques de la gare du Nord' and consisted in eating facilities and beauty corners. The idea was to off er com-muters the advantages of proximity (it is only a few metres between the shops and the escalators leading to the suburban train platforms, making it possible to shop without interrupting the mobility chain between two trains) (Demotz, 2007; Vieilliard, 2006).

These underground retail levels reinforce the vertical structure of the parts of the station open to passengers. As a result, there is now intense vertical and horizontal movement between the four levels, particularly at rush hour, although this does not create a universal mix. On the contrary, the occupancy and movement patterns in the station's diff erent levels are socially very distinct (Kleinman, 2012). The top level, set aside for the cross-Channel train, is mainly occupied by upper middle-class international customers, with large spending capacity, whereas the two underground levels are used by regional commuters travelling from and to the northern suburbs, the poorest in Ile-deFrance. Consequently, the eff orts of the company are now focus on a third generation of retail development in the cross-platform and in the Eurostar zone, where internal pro- spects off er a potential increase of $56 \%$ and $33 \%$ percent profitability per square metre thanks to more affl uent visitors (Figure 2).

\section{Mapping spatial patterns of change at Paris Gare du Nord between 2010 and 2017}

\section{Gare du Nord cross-platform redesigned as a 'servicescape'}

The changes made to the layout of these two levels between 2010 and 2017 show the application of retail and streaming strategies, or rather strategies of retail as flow. These new design principles have not been applied blindly. On the contrary, they have been applied pragmatically, to take account of the shallowness of the building, in which the distance between the shops situated against the back wall and the platforms is no more than

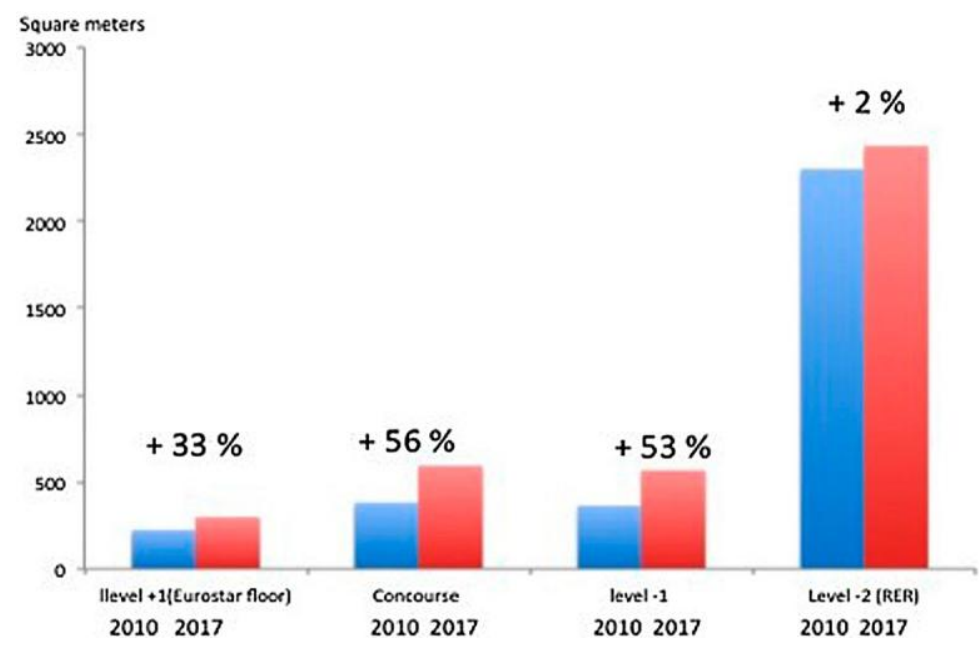

Figure 2. 2010-2017 retail area extension. 
30 metres. In 2010, this area was laid out around an arrivals and departures board, 4 escalators, and services and shops supplying basic services: fast or casual food and newspapers, plus a tobacconist near the entrance. Under the mezzanine for Eurostar passengers, there was a large waiting-room in the eastern corner mezzanine, and ticket counters running along the blind facade, not far from a row of ticket machines. In all, in 2010 the cross-platform housed 7 brands with 12 sales outlets, dominated by the Relay newspaper brand (which occupied $55 \%$ of the retail surface), the rest being mostly mediocre quality outlets (Figure 3).

This arrangement caused two types of pedestrian traffic problems. First, there was per-manent crowding in the middle of the platform, in front of the central noticeboard, which hampered flows onto or off the escalators, creating a shearing eff ect (movement of people blocked by a fixed and compact crowd) at rush hours. Second, the general congestion of the zone and the immobility of passengers around the noticeboard reduced the profitabil-ity of the shops located against the wall, which were also disadvantaged by their distance (approximately $20 \mathrm{~m}$ ) from the most attractive part of the hall and by the lack of light (because of their position under the mezzanine).

The change in traffi c flow organization and retail outlet location between 2010 and 2017 is highly noticeable. First, the central noticeboard has disappeared and been replaced by a

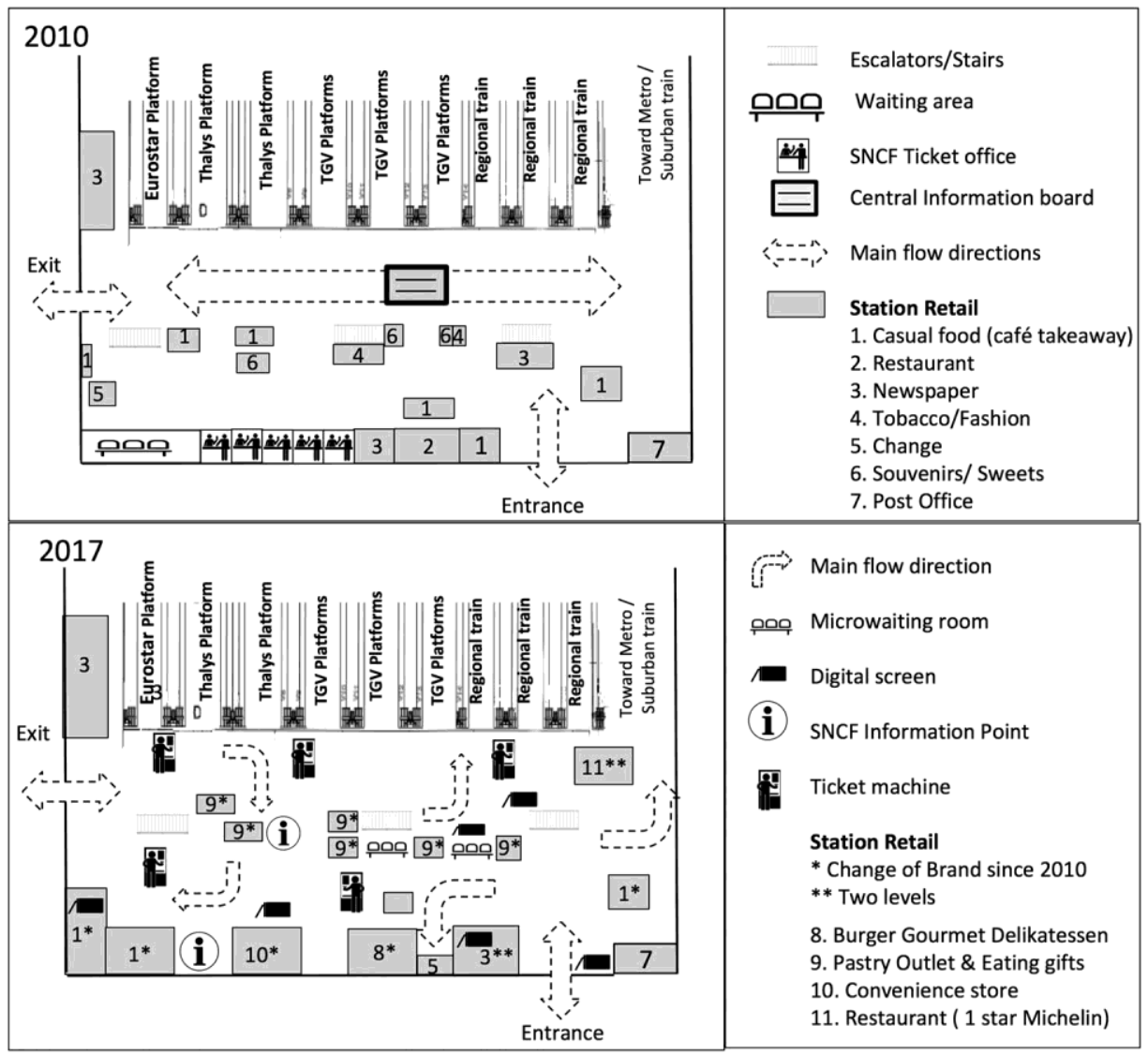

Figure 3. 2010-2017 changes at Gare du Nord Basement level. 
profusion of digital monitors, located in particular at the top of the escalators and at several points around the cross-platform (Photo 1). Second, the row of ticket offices has almost disappeared, since most tickets are now bought at machines or online. This has released space for movement and shops. The latter are no longer contained in small kiosks but in larger spaces, alternating with information points and short-wait microlounges (a quiet zone to the west is still set aside for longer waiting times). Better lighting and the design choices (plexiglass partitions) generate transparency and enlarge the visual field. The result, therefore, is a much denser use of space, reflected in increased room for movement and greater overall partitioning of functions. Travellers are dispersed and kept in perpetual movement throughout the whole station. For the same reason, screens have been placed in certain shops, which have themselves undergone several transformations: relocation and enlargement of certain outlets, diversification and renovation of the retail range. Yet, the dominance of the Relay brand has not been aff ected, but it is now a 'concept store' off ering communication devices, fine food (Fauchon), a café, a reading lounge, ... This shop is a kind of station in the station (Briard, 2016): it combines the functions of waiting-room, information desk and multibrand store. With the gradual renewal of the other leases, the railway operator has also moved the main snack and fast food outlets, off ering upmarket eateries and more diverse dining options. (Photo 2).

Moreover, the longitudinal distribution of the brands reflects the application of a diff erential in commerciality potential for diff erent types of travellers. In the east of the hall, near the street entrance, the post office, the tobacconist and an aff ordable food outlet enable morning commuters, who have the shortest allowance time (often less than $10 \mathrm{~min}$ ) to do routine shopping without wasting time. HS customers, who board in the middle of the cross-platform, have a longer allowance time, from 15 to $45 \mathrm{~min}$ and are exposed to a wider retail range, off ering opportunities for impulse buying (gifts, chocolate, cakes). Even if they resist temptation, they will see the same cakes on their return and may perhaps be prompted to buy. Finally, the area closest to the Eurostar and Thalys boarding point, to the west, boasts a particular concentration of 'chic' new brands, taking advantage

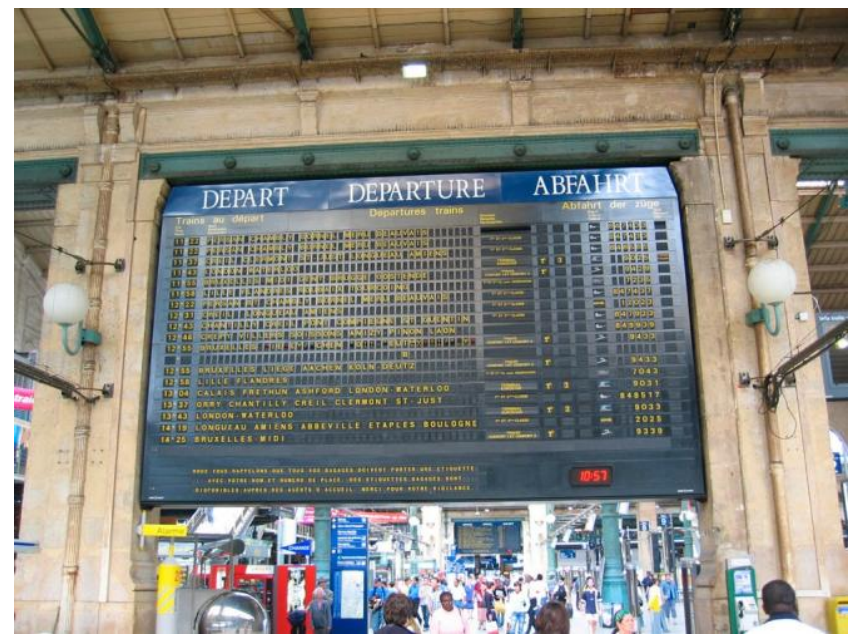

Photo 1. Information Board removed in november 2015 to avoid flow congestion at its bottom. 


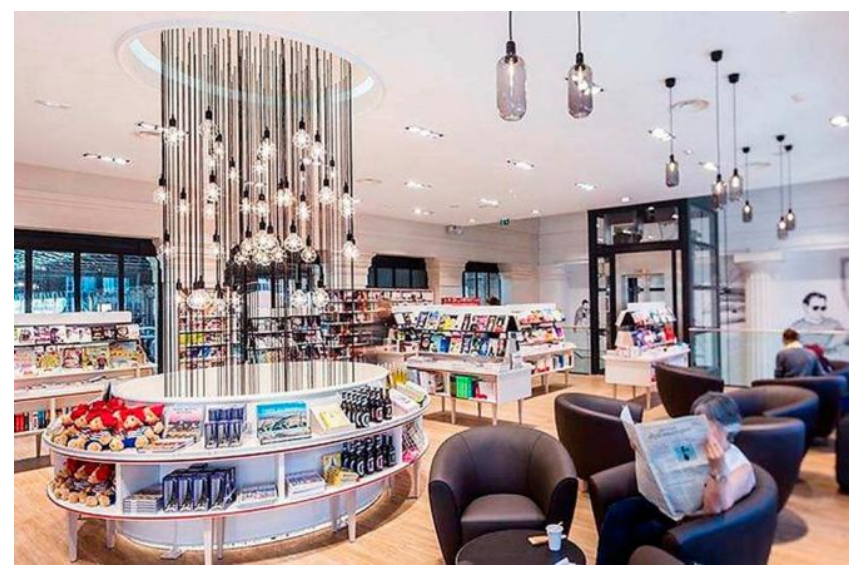

Photo 2. Interior of Gare du Nord Relay Store (Eurostar mezzanine) (photo of the author).

of maximum proximity to international customers with 'lab' stores testing out highquality pastry, with counters specializing in 'eclairs', 'cannelés', 'macaroons' and a considerable variety of modulable store formats (desk on wheels, pop-up shops).

Moreover, commerce in a station environment is a complex business. Railway operations influence service consumption because of intermodal changes and dwelling conditions. At Gare du Nord, the reason for crowding on the concourse is the number of connections. Between 87 and $89 \%$ of users of the four rail services (regional, conventional HS (Paris-Lille), Thalys and Eurostar) use the concourse to connect with regional lines, metropolitan RER lines and the metro. On the other hand, dwell times are determined by the numbers of passengers disembarking and boarding (especially at peak hours), the characteristics of the train and infrastructure, train arrival and departure processes, and the distribution of passengers along the platform. SNCF therefore made in-situ observations at an evening peak hour to estimate the relative and absolute numbers of people using various services (ticketing, eateries and information desk) and retail stores, for the diff erent types of trip and train service. It found that, at the busiest moment of the day, more than 2000 people are shopping, while a further 2500 are asking for information or buying a ticket or eating and drinking at one of the café terraces.

\section{Eurostar mezzanine as a 'stationscape' : food for the eyes}

In 2010, the Eurostar floor was divided into three very diff erent spaces for legal reasons aswell as because of specific architectural constraints. The corridor extended from the top of the escalator, which delivered the passengers into the queues, and then led to the Schengen border post, with customs and police inspection points. Then, the corridor turned right into a long but narrow shopping alley with a continous façade of 7 sales outlets. This shop-ping street, devoid of sitting and waiting spaces (perhaps to force people into the stores), ended in the third zone, the ticket inspection section, beyond which there was a waiting room where passengers were 'stored' before being allowed to walk downstairs andboard. Allowance time here was very long because of Schengen controls and the shops so scarce that, despite their ordinariness (fast food, newspapers), were already remarkablyprofitable (Figure 4). 


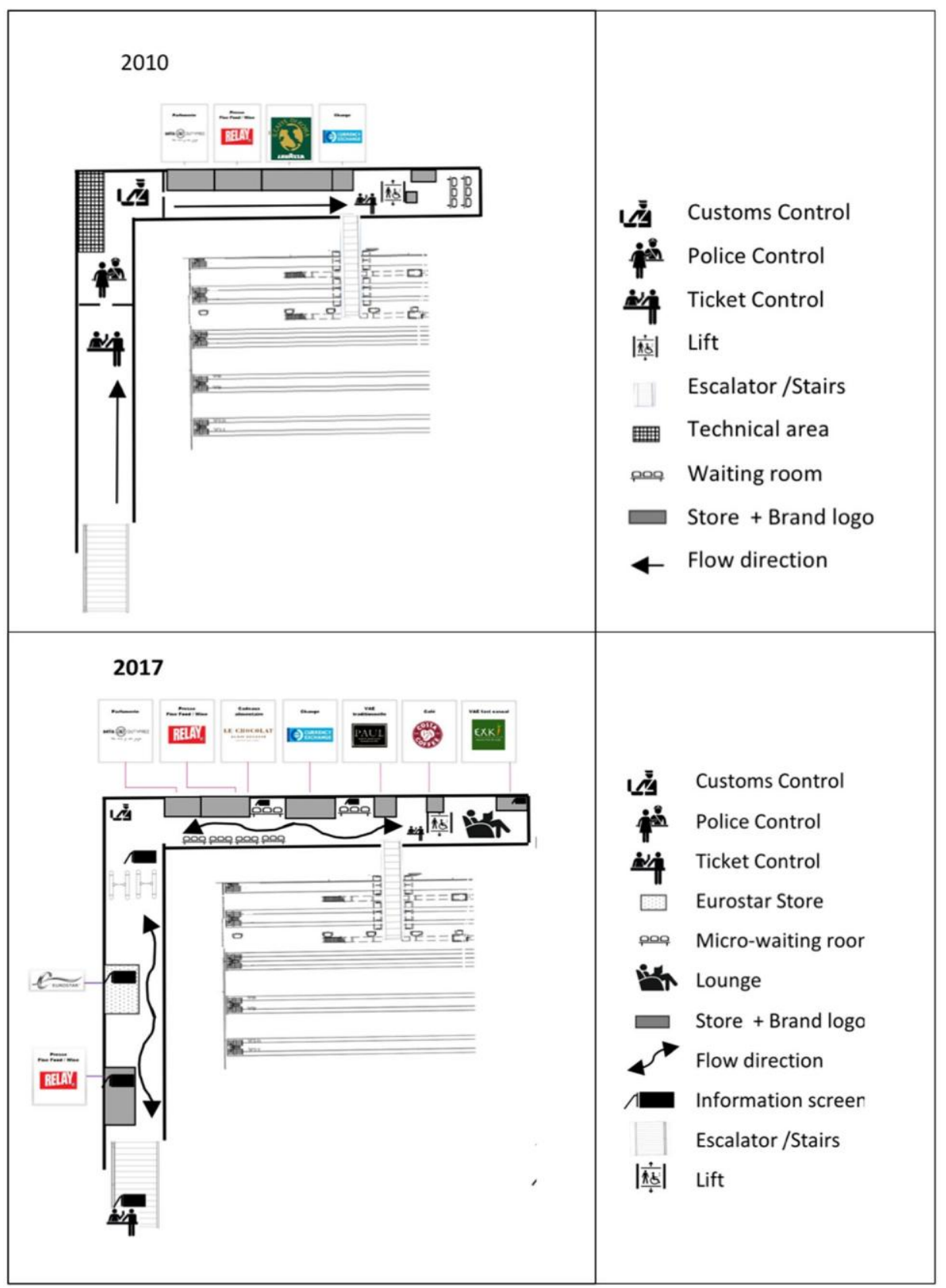

Figure 4. 2010-2017 changes at Gare du Nord Mezzanine.

In 2017, important changes are identifiable. With a small increase in the surface area accessible to the public (achieved by reducing the space allocated to the customs and the police offices, who are being moved to a zone without public access), pedestrian space hasbeen increased by a third and waiting areas by $86 \%$. Here, crowding takes a diff erent formbecause of the boarding arrangements. Passengers must wait at the police checkpoint, thenat boarding, but congestion has been reduced thanks to the installation of many more 
Table 2. Station design principles followed at Paris Gare du Nord.

\begin{tabular}{|c|c|c|}
\hline $\begin{array}{l}\text { 2010-2017 apparent modifications in } \\
\text { Gare du Nord spaces }\end{array}$ & Principles followed & Goals \\
\hline $\begin{array}{l}\text { Separation between micro-waiting areas } \\
\text { (in flow) and confort lounges (appart of } \\
\text { main flows) }\end{array}$ & $\begin{array}{l}\text { Segmenting user's typology: } \\
\text { Long wait: international lines } \\
\text { Short wait: national/regional lines }\end{array}$ & $\begin{array}{l}\text { Socio-spatial } \\
\text { reordening } \\
\text { Environmental } \\
\text { upgrading }\end{array}$ \\
\hline $\begin{array}{l}\text { Information and ticket office } \\
\text { reorganization }\end{array}$ & $\begin{array}{l}\text { Closing old ticket offices gives more space to } \\
\text { service and circulation and fosters digital } \\
\text { ticketing }\end{array}$ & $\begin{array}{l}\text { Station digitalization } \\
\text { Preparation to market } \\
\text { competition }\end{array}$ \\
\hline Retail growth in surface and diversity & $\begin{array}{l}\text { Answering user's needs and Fostering user's } \\
\text { movement throughout the whole platform }\end{array}$ & $\begin{array}{l}\text { Growth of revenues } \\
\text { Better fluidity }\end{array}$ \\
\hline $\begin{array}{l}\text { Relocation / Removal of Information } \\
\text { pannels }\end{array}$ & $\begin{array}{l}\text { Nudging techniques suggest adequate user's } \\
\text { behaviour and creat shopping opportunities }\end{array}$ & $\begin{array}{l}\text { Better fluidity } \\
\text { Better security } \\
\text { conditions }\end{array}$ \\
\hline Escalators and lanes multiplication & $\begin{array}{l}\text { Giving possibilities to circulate horizontally and } \\
\text { vertically, enjoying stationscape and limiting } \\
\text { congestion and queues at peak hours }\end{array}$ & $\begin{array}{l}\text { Flow management } \\
\text { Accessibility } \\
\text { Verticality }\end{array}$ \\
\hline
\end{tabular}

gateways and more technology (biometric passport and face recognition facilitates fluidity). The long passageway has been converted to a free strolling area, where people can shop and wait in comfort. The highly profitable shops have changed little and they off er is still more comparable to airport retail than to HS station retail, but their continuity is broken up by mini waiting rooms interspersed between them. Above all, Eurostar clients can enjoy the view below and admire all the station scape over the main concourse at a very long and shallow counter with barstool type seats, unless they prefer to visit the large and luxurious lounge after passing through the control points.

\section{Results: interpreting retail design as flow strategy}

\section{New spatial patterns for the deployment of nudging techniques}

The before/after comparison shows how SNCF is introducing traffic streaming as a way both to maintain movement and to focus attention on shopping opportunities. The precepts that guide the changes observed since 2010 are inspired by a fast-growing science of mobility, driven by transnational trends that draw on airport development principles and convergences as well as on railway station architecture, yet with some diff erences. (see Table 2) In fact, airport retail design and management greatly influenced the techniques of retail design in railway station. Until 2000, the majority of design manuals had a single entry for airport and station 'design for flows' (Blow, 1999) while others began to include chapters concerning diff erentiating between large and small airports, and several types of metro and railway stations (De Neufville \& Odoni, 2003).

Nevertheless, some of the inspiration behind the changes made to Gare du Nord is specific to SNCF and reflects its adjustment to a new legal, institutional and competitive environment. We have demonstrated with the empirical study the interdependence between processes intended simultaneously to make spaces of movement more efficient and retail outlets more profitable. This now raises further critical questions on the new nature of station spatiality and commerciality.

Our analysis shows that flow streaming generates additional consumption and greater profitability, not only because of the increase in passenger numbers or retail spaces, but 
through the intensification of HS station commerciality. The increase in the value of the average sales transaction and in purchase frequency, as well as the diversity of opportunities for consumption and shopping styles are part of a nudge strategy. The station operators are seeking to use aural, visual or digital messages to modulate the decisions of pedestrians, in order to encourage without forcing, to influence without pushing, and gently to prompt people, through the appeal of brands, or emulation of the flow, to move in the right direction, or to buy at the right time. Hence, the nudge strategy is now an operational as well as a scientific frontier in HS railway station development. A number of recent studies in Asia have gone in this direction, examining how travelling shoppers find their way and, at the same time, perceive and understand the station as a retail scape (Mazibuko \& Sharp, 2014). Others go further in exploring the common factors that determine choice of movement and the impulse to buy at stations (Seto, Hamada, Minemoto, \& Ikoma, 2010). Along similar lines, the new challenge for multidisciplinary research is to observe how stations can be designed as integrated shopping destinations (Simpson, 2015).

\section{Making stations profitable begins with improving their visual qualities}

The combination of retail and flow techniques is accompanied by a new emphasis on the three-dimensional visual characteristics of HS stations. It takes into account the conditions of spatial visuality and visibility and the diff erent perceptual regimes of HS station users(Hillier, Penn, Hanson, Grajewski, \& Xu, 1993).

The station is not flat but is perceived by any human being as a convex visual space, where any user is successively moving observer and observing mover (Brighenti, 2010). Hence, the pedestrian's behaviour arises from the succession of conic views presented as he moves, which at each moment defines the field of visibility and therefore the range of actions open to him. And the before and after studies conducted in Gare du Nord confirm that the rearrangement has brought about a change in visibility. The crossplatform, initially structured by large clusters (waiting at the back, shopping at the side, departure board in the middle) has been fragmented. Commercial intensificationhas infiltrated commerciality throughout the station (including moving and waiting areas) because of the proliferation of retail outlets. Already a place saturated with sensory and visual stimuli, the station space - a space both fragmented and filled - nudges the customer through a series of enticements, prompting two major forms of mobility.

Capo and Chanu explain that 'the newness is that the station represents a new space for the production of overall services, underpinned by diff erent dimensions of proximity' (Capo $\&$ Chanu, 2015). A first dimension encompasses the near visible field and defines a movement constructed by proximity. Within a visual field of some 10-20 metres, the customer perceives - simultaneously - a short empty space to move through, a few of informational or directional signals (signs, platform number) and some commercial message (shopwindow, brand, billboard ...). The act of buying no longer entails a break or a detour, but has arguably become a simple gesture of acceptance of the logic of streamed movement. Customers do not have visual or cognitive access to the whole pedestrian space and the entire commercial off ering, but they are able to navigate from one spot to another, in zigzags.

A second type of proximity and visibility is obtained by top down vistas. It lies in the construction of a new optical relation between movement in the station and the station's 
retail function. The mezzanine point of view, the installation of a two-level starred restaurant on the cross-platform, or the vertical extension of the Relay outlet, are some examples of the provision and commodification of a panoptic view of the flow. From above, the passenger can appreciate the long view, the wide spectrum, the aerial perspective of the whole station. This stationscape is a source of visual or sensory enjoyment that itself creates commercial value. Thus, the place with the best view of the station is no longer the station master's office, but the station's smartest retail outlet or restaurant (Van Ingelgem, 2015). From here, the stream is no longer a technical object, but becomes a pacified crowd. Thus, the traveller unconsciously consents to buy a more expensive sandwich, in an upmarket outlet, topologically perched above the fray, and the price includes the enjoyment of the show laid out before her as she eats. It is no accident that these aerial views are usually associated with places where access is limited (high restaurants and VIP lounges) (Photo 3).

\section{Trademarks as landmarks}

The in-depth study of the changes to Gare du Nord has more to add to our understanding of the connection between traffic streaming and retail layout. First, a reminder: retail outlets in stations have always played a role in spatial orientation. However, in the context of enhanced commercial density and traffic intensity, this role becomes even more essential. Today, one can no longer arrange to meet under the main information board, since it has gone, or under a digital screen, since there are dozens of them. So retail brands play an even more fundamental role than in the past. Their features (position, orientation, height, colour) punctuate perception of the station space. The station operator has interrupted the long commercial arrays (of stores or ticket kiosks) and broken up rows of more than two shop windows with recesses (mini waiting rooms), as seen in the Eurostar mezzanine, creating crenels in the visual field whose regularity facilitates the assessment of distances in long vistas, preventing monotony and uniformity. An examination of social networks shows easily that young people arranging to meet at Gare du Nord do not choose the rail company's information kiosks as their rendezvous point, but one

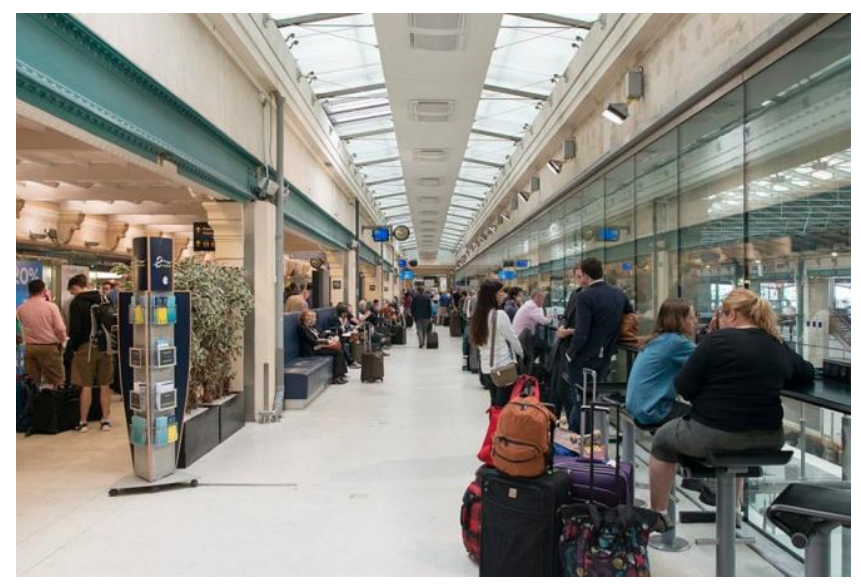

Photo 3. Stationscape: flow visual consumption, an added value in station retail (photo of the author). 
of the station's emblematic outlets. The more the station space fills up with discontinuities, the more layered and fragmented it is, the more the passages through it must be both marked and softened. Consequently, stores act not only as waymarks for the diff erent spaces, but become pivots and thresholds. Shop windows disappear, partitions become transparent, retail kiosks become convex, with rotundas, or acquire wheels, operating as junctions between zones.

\section{Conclusion}

Even before the new metamorphosis scheduled in the run-up to Olympic Bid 2024, the current alterations at Gare du Nord show how a process of flow engineering and a commercial strategy can come together and transform the conditions of movement and consumption. Though the figures of the rational pedestrian and the impulsive consumer continue to be conceptualized separately in the academic literature, they are beginning to merge in the minds of HS station managers. They no longer see the retail outlet only as an embellishment that contributes to service levels and customer satisfaction. Nor is retail just a tool that creates value for the station operator, as it is characterized in the marketing and economics literature. Retail may be used as an instrument that simultaneously reorders flows and turn those flows into fertile commercial streams. Reorganizing shops and flows, relocating information panels and ticket offices and machines, upgrading waiting rooms and facilities: all these elements are coordinated for a global transformation of the user's movement and experience.

The transferability of station retail design to other HS station contexts is still embryonic, although the opening of numerous HS lines and HS stations in emerging countries represents a market opportunity for expertise transfer. The ambiguity of importing retail models is highly visible in Agdal HS station, Morocco's biggest station (27 million users projected), which opened in 2018 along with the Tanger Rabat HS line. As a joint programme between the Moroccan rail company ONCF and global asset developer Sonae Sierra, the new station juxtaposes a 52,000 $\mathrm{m}^{2}$ mall (in a separate building) with a commercial program for 100 stores inside the HS station, organized on 3 levels. At the lowest level, airport-like luxury brands (mainly clothes and beauty stores), at platform level some basic services oriented to passenger needs (organized in a shopping gallery to avoid flow friction), and themed restaurants on the top level. This design threatens and does not complement the district commercial activity, and this shows the difficulty of combining the three objectives of station retail, which are profitability, customer oriented service and integration into a broader approach to urban retail geography. traveller needs and the integration of station stores in a wider urban development scheme.

Railway customer segmentation has long focused on purpose of travel and has been based on dualistic categories (business vs leisure, commuting vs long distance, national vs international/tourist, high value and loyalty card vs low value). Today, satisfaction surveys, purchasing questionnaires and geolocation pathway models off er very diff erent ways of exploring station users' attitudes and preferences. New criteria are gaining impor- tance in retail development strategies. Attention is more and more paid to traveller time constraints (the dwelling or margin time), to stress and to mental load. Consequently, station shopping provision is positioned as an opportunity for people to escape stressand to find a few minutes to disconnect, to enjoy some 'me time' or socialize in a 
group. Focus groups may help hierarchizing the impact of brands, in order to predict passenger route choice. Another avenue for research would be to develop a more in-depth cognitive approach to movement in stations in order to better understand how the pedestrian drifts in radar mode, from one attractor to another, and how they balance between positive and negative stimuli. To do this would also entail exploring the use of the electronic devices that increasingly influence navigation, ticket buying and platform finding behaviours.

\section{Disclosure statement}

No potential conflict of interest was reported by the author.

\section{References}

Anic, I.-D., Radas, S., \& Lim Lewis, K. S. (2010). Relative eff ects of store traffi c and customer traffi c flow on shopper spending. The International Review of Retail, Distribution and Consumer Research, 20(2), 237-250.

Ban, D. (2008). Les sciences sociales face à la gare bilan et lecture critique [French social sciences and railway station: An evaluation and a critical reading]. Revue d'histoire des chemins de fer, 38, $11-18$.

Banos, A., \& Pare, A. (2009). Simuler les déplacements piéton dans une station de métro : une approche à base d'agents. Revue Internationale de géomatique, 19(3), 277-302.

Baron, N., \& Roseau, N. (2016). Les gares au miroir de l'urbain [Stations in the mirror of cities]. Revue Flux, 1-2, 103-104, 1-8.

Battegay, A., \& Tarrius, A. (1995). La gare du Nord et ses environnements urbains: Explorations d'anthropologie urbaine. Paris: Ministère de l'Equipement, Plan Urbain.

Bayart, D. (1996). L'information voyageurs en Gare du Nord, Pertinence et système organisationnel [Passenger information at Gare du Nord: pertinence and organisation systems]. Les Annales de la Recherche Urbaine, 71, 113-119.

Bertolini, L., \& Spit, T. (1998). Cities on rails: The redevelopment of railway station areas. London, New York: E F\&N Spon.

Blow, C. (1999). Terminal and transport interchanges. In A. David (Ed.), Metric handbook planning and design (2nd ed., pp. 125-144). Oxford: Reed Elsevier and Architectural press.

Bowie, K. (1996). De la gare du $19^{\mathrm{e}}$ siècle au lieu mouvement: évolution ou rupture? [From 19th century railway stations to movement places]. Annales de la recherche urbaine, 71, 14-23.

Briard, C. (2016, October). Le flagship de Relay à la gare du Nord [Relay's flagship at Gare du nord], Les Echos Edition $11^{\text {th }}$ of october, page 14.

Brighenti, A. M. (2010). Visibility in social theory and social research. Basingstoke. Hampshire: Palgrave Macmillan.

Capo, C., \& Chanu, O. (2015). La gare moderne, vers un espace de service global [Modern station, toward a global space of services]. Economies et sociétés, 3(16), 385-416.

Cidell, J., \& Pryterch, D. (2015). Transport, mobility and production of urban space. New York: Routledge.

Clot-Goudard, R., \& Tillous, M. (2008). L'espace du réseau: du flux au territoire. Le tournant pragmatiste engagé par Isaac Joseph [Network's space: from flow to territory: Isaac Joseph's pragmatist turn]. Tracés, 15, 107-126.

Clozier, R. (1942). La gare du Nord (Unpublished doctoral dissertation), Paris: Baillère.

Daamen, W., \& Hoogendoorn, S.-P. (2004). Experimental research on pedestrian walking behavior. In Transportation research board annual meeting (pp. 1-16). Washington, DC: National Academy Press. 
Dang Vu, H., \& Jeanneau, H. (2008). Concevoir un espace de transit et de consommation: la gestion de site dans les gares parisiennes [Conceiving transit and consumption space: site management in parisian stations]. Espaces et sociétés, 135(4), 45-62.

Debayles-Oki, K., \& Doumas, E. (2006). Les grandes gares dans les grandes villes :situation actuelle de leurs configurations spatiales et off res commerciales à Osaka, Londres et Paris. Paris: Editions Techniques Ferroviaires.

Demotz, P. (2007). Les commerces dans les gares: un service dans la chaîne du voyage [Stores in stations: A service in the trip chain]. Revue Générale des Chemins de Fer, 161, 53-57.

De Neufville, R., \& Odoni, A. R. (2003). Airport systems: Planning, design and management. New York: McGraw-Hill.

Desruelles, V. (2009). Commerce en zones de transit: analyse du changement de paysage concurrentiel et perspectives du marché [Retail in transit areas: competitive change analysis and market perspectives]. Paris: XERFI consulting.

Duchemin, C. (1999, February). Gares et commerces: un mariage d'avenir [Stations and commerces: A prosperous marriage]. Le Rail, 73, 24-29.

Favin-Lévêque, J. C. (2005). La politique de services de la direction des gares et de l'escale [Service policy at SNCF direction of Stations and stops]. Revue générale des chemins de fer, 135, 19-30.

Fruin, J. J. (1971). Pedestrian planning and design. New York: Metropolitan ass. Of urban designers and Environmental planners.

Gary, D. (1995). Bringing stores to shoppers - not shoppers to stores. International Journal of Retail \& Distribution Management, 23(1), 18-23.

Gasnier, A. (2007). Les temps de mobilité des consommateurs au coeur des nouvelles logiques d'implantation de l'off re commerciale [Consumers Mobility Time in New Retail Trade Logics of Locating Stores]. Espace, Populations, Sociétés, 2-3, online. Retrieved from /index2143.html.

Gibson, J. J. (2015). The ecological approach to visual perception. New York: Psychology Press Taylor\&Francis. (First edition 1986).

Goff man, E. (1963). Behaviour in public places. New York: Free Press.

Goss, J. (1993). The "magic of the mall": An analysis of form, function, and meaning in the contemporary retail built environment. Annals of the Association of American Geographers, 83(1), $18-47$.

Haans, H. (2011). Evaluating retail format extensions: The role of shopping goals. Journal of Retailing and Consumer Services, 18(5), 389-396.

Hale, C. (2013). History and prospects of the rail station. Journal of Urbanism: International Research on Placemaking and Urban Sustainability, 6(1), 72-91.

Hale, C., \& Miller, M. (2013). Amenity and opportunity at rail stations. Australian Planner, 50(1), 44-54.

Hillier, B., Penn, A., Hanson, J., Grajewski, T., \& Xu, J. (1993). Natural movement: Or, configuration and attraction in urban pedestrian movement. Environment and Planning B: Planning and Design, 20, 29-66.

Joseph, I. (1995). Gare du Nord mode d'emploi. Paris: Éditions Recherches, RATP.

Kärrholm, M. (2009). To the rhythm of shopping—on synchronisation in urban landscapes of consumption. Social \& Cultural Geography, 10(4), 421-440.

Kleinman, J. (2012). The Gare du Nord: Parisian topographies of exchange. Ethnologie française, 42 (3), 567-576.

Les Échos Etudes. (2013). Les stratégies gagnantes pour le commerce dans les zones de flux: gares, aéroports, autoroutes, quartiers de flux. Paris: Executive briefings from Les Echos consulting.

Löfgren, O. (2008). Motion and emotion, learning to be a railway traveler. Mobilities, 3(3), 331-351.

Mazibuko, N. E., \& Sharp, G. D. (2014). Travelling shoppers' perceptions of servicescape of the bus and railway station retail environment. Journal of Contemporary Management, 11(1), 62-81.

Merle, P., \& Fauchon, A. (2018). Droit commercial Sociétés commerciales. Paris: Dalloz.

Monnet, J., \& Staszak, J.-F. (2008). Le consommateur ambulant: mobilités, stratégies et services [The mobile consumer: mobilities, stratégies, services]. Espaces et sociétés, 135(4), 19-24.

Paris, S. (2007). Caractérisation des niveaux de services et modélisation des circulations de personnes dans les lieux d'échanges [Level of service characterization and agent circulation modelization in 
hubs] (PhD Report). University Rennes I, n 3594. Retrieved from ftp://ftp.irisa.fr/techreports/ theses/2007/paris.pdf.

Peek, G.-J., \& Van Hagen, M. (2002). Creating synergy in and around stations: Three strategies for adding value . Transportation Research Record: Journal of the Transportation Research Board 1793(1), 1-6.

Périer, M. (2003, July August). Les boutiques de gare du Nord [Gare du nord's shops]. Revue générale des chemins de fer, 119, 23-27.

Perrin, P. (1998). Les commerces en gare, la valorisation commerciale. Revue générale des chemins de fer, 1998(4), 23-101.

Pięt, A. (2012). Shopping centre as a part of the contemporary railway station complex $12^{\text {th }}$ International scientific conference VSU 2012, University of Structural engineering and architecture, Sofia, Bulgaria. Retrieved from https://www.vsu.bg/upload/VSU2012_Vol2-6-Piet.pdf

Pitsiava-Latinopoulou, M., \& Iordanopoulos, P. (2012). Intermodal passengers terminals: Design standards for better level of service. Procedia - Social and Behavioral Sciences, 48, 3297-3306.

Pouvelle, P. (1998). Les services en gare et la satisfaction de la clientèle [Station services and customer satisfaction]. Revue générale des chemins de fer, 1998(4), 15-21.

Proust, J. (1996). L'attention sélective et la trame de l'expérience dans la gare du Nord. Paris: Ecole Polytechnique Créa.

Ribeill, G. (1996). Les métamorphoses de la grande gare française. Les Annales de la recherche urbaine, 71, 54-65.

Riot, E. (2014). A European perspective on the planning of major railway stations: Considering the cases of St Pancras Station and Paris Gare du Nord. Tranport Planning Review, 85(2), 191-202.

Ropert, P. (2017) City booster les gares à l'aube d'une révolution [City booster: station's revolution dawn]. Paris: Editions Débats Publics.

Ross, J. (2000). Railway stations: Planning, design and management. Oxford: Architectural Press.

Seto, K., Hamada, T., Minemoto, T., \& Ikoma, K. (2010). Application of pedestrian flow simulation to railway station layout design: An approach based on collaboration with customers. Hitachi Review, 59(5), 234-239.

Shankar, V., Kleijnen, M., Ramathan, S., Rizley, R., Holland, S., \& Morrissey, S. (2016). Mobile shopper marketing: Issues, current insights, and future research avenues. Journal of Interactive Marketing, under press.

Simpson, H. (2015, July). Retail and rail - the design challenge [Editorial]. Building Construction Design Monday.

SNCF, Retail\&Connexions. (2016). La gare, nouvelle adresse de centre-ville [Station, new city center address], Paris, 35 p.

Traoré Porna, I. (2008). Systèmes temporels et rythmes urbains du complexe d'échanges de la Gare du Nord Paris: outils de compréhension de la ville du présent comme un chronotope urbain [Temporal systems and urban rythms at Gare du Nord: comprehension tools of present city as urban chronotopy], (Unpublished doctoral dissertation s). University Pierre Mendès France Grenoble - Universita Politecnico Milano.

Van Ingelgem, G. (2015). Se restaurer en mobilité ferroviaire: Bruxelles et ses quartiers de gare depuis 1835: Innovations, échanges, mobilités [Eating in railway mobility: Brussels and its station districts sice 1835] (Ongoing Doctoral dissertation), Vrije universitet Brussel, Université de Tours.

Vieilliard, F. (2006). La politique de valorisation des gares par les commerces [Station's valorization policy by shops]. Revue Générale des Chemins de Fer, 152, 7-16.

Wilmotte, J. M., Mairie de Paris, AREP \& SNCF (2016). Gare du nord Transformations 2015 -2023, $52 \mathrm{p}$.

Xue, C. Q. L., Ma, L., \& Hui Ka, C. (2012). Indoor public space: A study of atria in mass stransit railway complexes in Hong Kong. Urban Design International, 17(2), 87-105.

Yamashita, Y., Uchiyana, H., \& Hibino, N. (2007). A behavioral analysis of passengers' railway station facilities. Journal of the Eastern Asia Society for Transportation, 7, 808-816.

Zemp, S., Stauff acher, M., Lang, D. J., \& Scholz, R. W. (2011). Classifying railway stations for strategic transport and land use planning: Context matters!. Journal of Transport Geography, 19(4), 670-679. 